\title{
Health Risk Assessment of Heavy Metals in Consumption of Vegetables Irrigated with Tin Mine Pond Water in Jos - South, Plateau State
}

\author{
G. M. Mafuyai, S. Ugbidye and G. I. Ezekiel
}

\section{ABSTRACT}

The water range from $\mathrm{Pb}(1.439$ - 1.715), $\mathrm{Cu}(0.234$ - 0.377), $\mathrm{Cd}(0.838-$ 1.346), Zn (0.448 - 1.110), Cr (0.144 - 0.794), Mn (0.777 - 2.011) and As $(0.584-1.341) \mathrm{mg} / \mathrm{L}$. The range in soil was $\mathrm{Pb}(67.5-120), \mathrm{Cu}(8.51-$ 32.5), Cd (0.21 - 1.72), Zn (70.8 - 85.6), Cr (15.8 - 29.5), Mn (14.6 - 19.1) and $\mathrm{As}(52.0-198) \mathrm{mg} / \mathrm{kg}$ and in the vegetables in the range of $\mathrm{Pb}(0.177$ - 0.545), Cu (0.073 - 0.748), Cd (0.005 - 0.019), Zn (0.264 - 0.915), Cr $(0.089-0.158)$, Mn $(0.162-0.253)$ and As $(0.032-0.245) \mathrm{mg} / \mathrm{kg}$. The study shows that the transfer coefficient of the heavy metals to vegetable was less than one $(<1)$. The estimated daily intake (DIM) of heavy metals from vegetables irrigated with tin mine pond water were in the order: $\mathrm{Cd}$ $>\mathrm{Zn}>\mathrm{Mn}>\mathrm{Cr}>\mathrm{Cu}>\mathrm{Pb}>$ As. The health risk index (HRI) of all the studied heavy metals indicated that all vegetables were safe with no risk to human health except for $\mathrm{Cd}$. health risk assessment of heavy metals in consumption of vegetables irrigated with tin mine pond water in Jos South, Plateau State was investigated. The concentration of heavy metals in the tin mine pond.

Keywords: Contamination, Health Risk Index, Heavy Metals.

\author{
Published Online: September 14, 2020 \\ ISSN: $2684-446 \mathrm{X}$ \\ DOI : 10.24018/ejgeo.2020.1.5.21

\section{G. M. Mafuyai*} \\ Department of Chemistry, Faculty of \\ Natural Sciences, University of Jos, \\ Nigeria. \\ (e-mail: godwinmaf002@gmail.com) \\ S. Ugbidye \\ Department of Chemistry, College of \\ Sciences, University of Agriculture \\ Makurdi, Nigeria.

\section{G. I. Ezekiel} \\ Department of Chemistry, Faculty of \\ Natural Sciences, University of Jos, \\ Nigeria. \\ *Corresponding Author
}

\section{INTRODUCTION}

Heavy metals contamination is a major problem of our environment and they are also one of the major contaminating agents of our food supply. This problem is a concern all over the world, especially in developing countries. The tradition of growing vegetables within and at the edge of industrial mine areas of cities is very old. It is revealed that most of these cultivated lands are contaminated with heavy metals contributed through mining waste water irrigation [1].

Tin is said to be one of the oldest mineral resources known to man as its strategic importance was recognized as far back as some 300 years ago when its hardening effects on copper was discovered [2]. Since then, tin ore has been mined in several parts of Nigeria including Zaria, Kano, Bauchi, Ilesha and Jos provinces, with over $80 \%$ of the production coming from the Jos Plateau [3]. Mining gives rise to large amount of excavated overburdens dumped on the surface (mine spoil) and deep mine ponds; this may contain various minerals and heavy metals, some of which are toxic in nature and affect the environment when their concentration exceeds the permissible levels. Surface runoff and wind erosion from mining sites could cause increase in concentration of the heavy metals in local biota, and have more significant effect on the ecosystem which may lead to geo-accumulation and subsequent bio-accumulation and biomagnifications in the food chain [4].
Water is an essential component of life, fresh water constitute about $3 \%$ of the total water on the earth surface, only $0.01 \%$ of this fresh water is available [5], with two thirds of the earth's surface covered by water and the human body consisting of $75 \%$ of it, it is evidently clear that water is one of the prime elements responsible for life on earth. Regrettably, even this small portion of fresh water is under pressure due to anthropogenic sources due to rapid growth in population and industrial activities [6].

Scarcity of fresh water is the main driving force towards the utilization of tin mine pond water for irrigating vegetables. Long-term mine pond water irrigation practice enriched heavy metals in soil thus; vegetables cultivated in metals enriched soil accumulate heavy metals in their tissues [7]. Heavy metals are the main pollutants and elements of risk in drinking water [8]. Investigation on water contamination by heavy metals has become the prime focus of environmental scientists in recent years [9].

Soil contamination with metals is a primary route of toxic elements exposure to humans as they can enter the human body by consumption of contaminated food crops, water or inhalation of dust [10]. It is evident that more than $70 \%$ of dietary intake of heavy metals is contributed to food chain [11]. The prolong consumption of foodstuff contaminated with heavy metals may lead to unceasing accumulation of toxins in the liver and kidney of humans resulting in disturbances of biochemical processes such as liver, kidney, cardiovascular, nervous and bone disorders [12], [13]. 
Vegetables are known to be good absorber of heavy metals from the soil and the danger lies in its ability to accumulate in the bodies of local residents [1]. Human and animal need a certain percentage of these elements that might happen on the part of the plant through the food chain [80]. The accumulation of heavy metals and metalloids in agricultural soils is of increasing concern due to the food safety issues and potential health risks as well as its detrimental effects on soil ecosystems [79].

\section{A. Human Health Risk}

Human health risk assessment is considered as the characterization of the potential adverse health effects of humans as a result of exposures to environmental hazards [13]. This process employs scientific tools to identify and measure a hazard, determine possible routes of exposure, and finally use that information to calculate a numerical value to represent the potential risk [14].

Mining wastewater used in irrigation induced heavy metals accumulation in vegetables and heavy metals associated risk assessment for consumers. Human are exposed to the risk through the consumption of vegetables contaminated with heavy metals. Most consumers are not aware with the source of the produce and the use of polluted irrigation water [24].

The health risk of heavy metals depends on the nature, concentration in vegetables, amount in vegetable consumed and so on. Health risk assessment of heavy metals in contaminated vegetables is extensively studied in developed countries [15], [16], [17], [18], [19] however, little information is available in Nigeria with very few published data on heavy metals Contamination in vegetables is available [7], [20], [21], [22].

A human health risk assessment involves four steps which are: hazard identification, dose-response assessment, exposure assessment, and risk characterization. Health risk assessment classifies elements as, carcinogenic or noncarcinogenic. The classification determines the procedure to be followed when potential risks are calculated. Noncarcinogenic chemicals are assumed to have a threshold; a dose below which no adverse health effects will be observed where an essential part of the dose-response portion of a risk assessment includes the use of a reference dose (RfD). Also, carcinogens are assumed to have no effective threshold. This assumption implies that there is a risk of cancer developing with exposures at low doses and, therefore, there is no safe threshold for exposure to carcinogenic chemicals. Carcinogens are expressed by their Cancer Potency Factor [82]. Environmental abatement is almost lacking due to lack of environmental management and un-operational environmental laws. Irrigation with tin mine pond water is a common practice in the peri- urban Jos - South Local Government Area in Plateau State, Nigeria [23].

The cultivation of vegetables crops with tin mine pond water is a common practice in Jos- South, Plateau State. Local farmers in the area uses the surface tin mine pond water to irrigate their agricultural fields for cultivation of vegetable crops. It has been reported that serious health problems can develop as a result of consumption of dietary foodstuffs contaminated with toxic heavy metals [83]. Therefore, the study is conducted to assess the heavy metal contamination in soil, resulted uptake by the vegetables and its eminent transfer to the food chain which assist in evaluating the related health hazards linked with.

\section{MATERIALS AND METHODS}

\section{A. Study area}

The study areas lie between latitude $9^{\circ} 46^{\prime} \mathrm{N}$ to $9^{\circ} 50^{\prime} \mathrm{N}$ and longitude $8^{\circ} 52^{\prime} \mathrm{E}$ to $8^{\circ} 55^{\prime} \mathrm{E}$. The areas played host to a lot of mining activities by foreign companies such British Mines Corperation Limited, Bisichi Jenta Limited, Gold and Base Corporation [24].

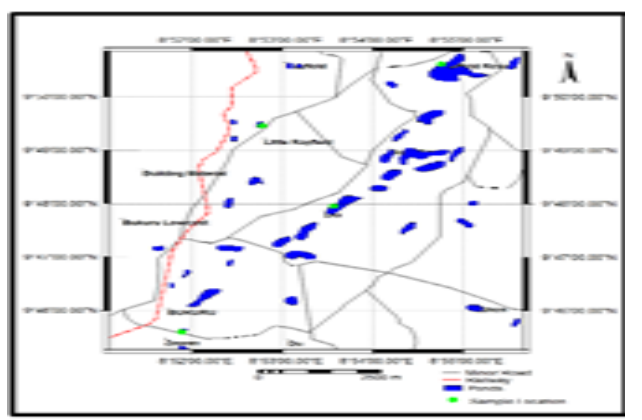

Fig.1 Map of Jos - South Showing Study Mined Ponds Sites

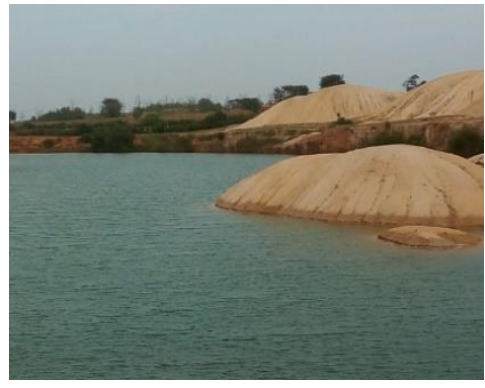

a)

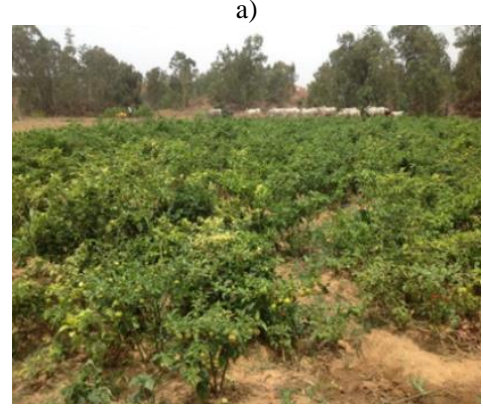

c)

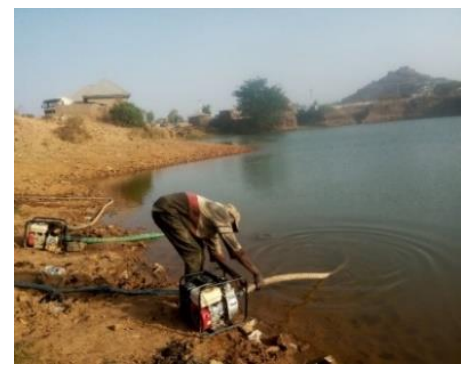

b)

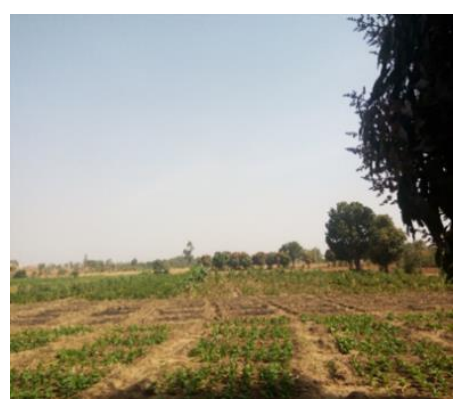

d)
Fig. 2. Typical (a), mining pond (b) irrigation of pump (c) garden egg farm (d) pepper farm.

\section{B. Sampling and Determination of Heavy Metals in Tin Mine Pond Water}

High-density polyethylene bottles were rinsed with metalfree detergent and soaked in $10 \% \mathrm{HNO}_{3}$ acid overnight and finally washed thoroughly with metal-free deionized water [25]. The bottles were used for collection of water samples from the tin mine ponds that were used in irrigating farms and taken to Chemistry Laboratory University of Jos, Nigeria and stored at $40 \mathrm{C}$ in a refrigerator.

About $100 \mathrm{~mL}$ of the water sample was taken into a 250 $\mathrm{mL}$ conical flask. Exactly $5 \mathrm{~mL}$ of conc. $\mathrm{HNO}_{3}$ was added and covered with a ribbed watch glass and evaporated to 20 $\mathrm{mL}$ on a hot plate. After which $5 \mathrm{~mL}$ each of $\mathrm{HNO}_{3}$ and 
$\mathrm{HClO}_{4}$ was added cooled beaker between additions. The sample was evaporated again on a hot plate until dense white fumes of $\mathrm{HClO}_{4}$ just appeared. The Sample was then cooled, diluted with metal-free distilled water and then filtered through Whatman No. 42 filter paper. The Filtrate was transferred to a $50 \mathrm{~mL}$ volumetric flask and diluted to mark with metal-free distilled water. Reagent blank was prepared following same procedure using metal - free distilled water. The clear solution obtained after digestion was analyzed for lead $(\mathrm{Pb})$, manganese $(\mathrm{Mn})$, chromium $(\mathrm{Cr})$, cadmium $(\mathrm{Cd})$, zinc $(\mathrm{Zn})$, cupper $(\mathrm{Cu})$ and arsenic $(\mathrm{As})$ by atomic absorption spectrophotometer (AAS). 2.3 Soil sampling and determination of heavy metals

Soil from the irrigated farms were collected by digging 0 - $20 \mathrm{~cm}$ depth, using a steel soil auger, non-soil particles were removed from the soil and the soil kept in tagged polythene bags. The soil samples were air-dried and sieved to $<0.25 \mathrm{~mm}$, then stored in desiccators [26], prior to analysis of heavy metals. About $5 \mathrm{~g}$ of dried and sieved subsoil sample were taken into $100 \mathrm{~mL}$ conical flask and digested with $20 \mathrm{~mL}$ of $1: 1 \mathrm{HNO}_{3}$ covered with a watch glass. Then the sample was evaporated to $8 \mathrm{~mL}$ on a hot plate. After cooling, $10 \mathrm{~mL}$ of $\mathrm{HClO}_{4}$ and $20 \mathrm{~mL}$ of metalfree distilled water added. Then the sample was again evaporated to $10 \mathrm{~mL}$ on the hot plate. After cooling, the sample was filtered through Whatman No. 42 filter paper and the filtrate transferred to a $100 \mathrm{~mL}$ volumetric flask and make up to mark with metal-free distilled water [27]. The concentrations of $\mathrm{Pb}, \mathrm{Cr}, \mathrm{Cu}, \mathrm{Cd}, \mathrm{Zn}, \mathrm{Mn}$, and $\mathrm{As}$, were determined using Atomic Absorption Spectrophotometer [28].

\section{Collection of plant samples and digestion for metal analyses}

The vegetables; garden egg (Solanum melongena), Spinach (Spinacia oleracea L.), family: Amaranthaceae and Tomato (Lycopersicon esculatum L.), family: Solanaceae, red pepper (Capsicum anum), Carrot (Daucus carota subsp. Sativus), family: Apiaceae; and cabbage (Brassica oleracea) were collected in replicates and stored in a labelled polythene sampling bags. The samples taken to the laboratory and washed with tap water to remove any kind of deposition like soil particles. The edible parts of the vegetables were then dried and ground into powdered formed.

One gram of each milled homogenized sample was weighed using an analytical digital weighing balance into a conical flask. Exactly $5 \mathrm{~mL}$ of $60 \%$ hydrochloric acid $(\mathrm{HCl})$ and $10 \mathrm{~mL}$ of $70 \%$ nitric acid (HNO3) was added into the weighed samples. The sample mixture was digested with moderate heat $\left(50^{\circ} \mathrm{C}\right)$ on a hot-plate until white fumes evolved, making it brownish solution. The heat was intensified further for few minutes to expel off most of the hydrochloric acid $(\mathrm{HCl})$. Exactly $50 \mathrm{~mL}$ of distilled water was added into the solution and heated for a few minutes, allowed to cool before being filtered through whatman No. 42 paper $(11 \mu \mathrm{m})$ into a dispensed transparent plastic container. The filtered sample were left to stand for few minutes for the aspiration of the element and then analyzed for heavy metals concentration using Atomic Absorption Spectrophotometer (AAS).

\section{Quality control}

The chemical used were purchased from MERCK Chemical Germany agent in Lagos Nigeria. Double deionized water was used for solution preparation and glassware were washed with $10 \% \mathrm{HNO}_{3}$. Standards were prepared for each metal from stock solution to calibrate the instrument. Precision and accuracy of analysis were checked through repeated analysis against NIST standard reference material SRM 1570A for vegetables, RM 1643E for water and SRM 2709 for soil for heavy metals.

\section{E. Data Analysis}

\section{Transfers factor}

Transfers factor (TF) was calculated to understand the extent of risk and associated hazard due to wastewater irrigation and consequent heavy metals accumulation in edible portion of test vegetables [29].The concentration of heavy metal in extracts of vegetables and soils on dry weight (DW) basis, respectively.

$$
\mathrm{TF}=\frac{\mathrm{C}_{\text {plant }}}{\mathrm{C}_{\text {soil }}}
$$

The ratio " $>1$ " means higher accumulation of metals in plant parts than soil [30]. If the transfer coefficient of a metal is greater than 0.50 , the plant will have a greater chance of the metal contamination by anthropogenic activities [31].

\section{Daily intake of metals (DIM)}

The Daily intake of metals (DIM) to the exposure pathway of heavy metals to human through ingestion of vegetables grown on wastewater irrigated soils [32]. Moreover, the DIM in this exposure pathway was determined by the multiple of the concentration in the vegetable on dry weight basis.

$$
\mathrm{DIM}=\frac{\mathrm{C}_{\text {vegetable }} \mathrm{X} \mathrm{C}_{\text {factor }} \mathrm{X} \mathrm{C}_{\text {food intake }}}{\mathrm{B}_{\text {average weight }}}
$$

where $\mathrm{C}_{\text {vegetable }}, \mathrm{C}_{\text {factor }}, \mathrm{D}_{\text {food intake }}$ and $\mathrm{B}_{\text {average weight }}$ represents the concentrations of heavy metal in vegetables (milligrams per kilogram) on dry weight basis, conversion factor for fresh to dry weight of vegetables (0.085) [33], daily intake of vegetables ( $0.345 \mathrm{~kg}$ per person per day for adults) and average body weight (55.90 kg for adults), respectively.

\section{Health risk index (HRI)}

Health risk index (HRI) assessment of consumers from the intake of vegetable contaminated with metals is characterized by using HRI. If, HRI is less than 1, there will not be obvious risk for exposed population and vice versa. The HRI is obtained by dividing the daily intake of metals (DIM) by the reference oral doses (RfD).

$$
\mathrm{HRI}=\frac{\mathrm{DIM}}{\mathrm{RfD}}
$$

where

Reference oral doses (RfD) for $\mathrm{Pb}, \mathrm{Mn}, \mathrm{Cr}, \mathrm{Cd}, \mathrm{Zn}, \mathrm{Cu}$ and As are $0.0035,0.033,1.5,0.001,0.30,0.04$, and 0.0003 $\mathrm{mg} / \mathrm{kg}$. If the value of HRI is less than 1 then the exposed population is said to be safe [34]. 


\section{RESUlts AND DiscUSSION}

A. Heavy metals concentration in mine pond water $(m g / L)$

Lead (Pb): Lead in the mine pond water used in irrigating the agricultural fields show a mean concentration of $1.62 \pm 0.1 \mathrm{mg} / \mathrm{L}$ However, the value obtained in this work is higher compared to that $(0.08 \mathrm{mg} / \mathrm{L})$ reported [35] and lower to that $(3.18 \mathrm{mg} / \mathrm{L})$ reported [36]. The value of $\mathrm{Pb}$ in both site studied are within the prescribed standard of irrigation [37]. Table 1 shows that the $\mathrm{Pb}$ concentration in tin mine pond positively correlated with $\mathrm{Cd}$ and negatively correlated with $\mathrm{Cr}$. Higher lead concentration in the tin mine pond water agree with the findings of [18], [38], [39].

Copper $(\mathbf{C u})$ : The mean concentration of $\mathrm{Cu}$ in tin mine pond water in the three studied areas $0.43 \pm 0.01 \mathrm{mg} / \mathrm{L}$ (Fig. 2 ). The concentration of $\mathrm{Cu}$ in tin mine pond water exceeds the recommended limits prescribedfig by FAO/WHO [37]. In the tin mine pond water $\mathrm{Cu}$ positively correlated with $\mathrm{Cd}$, $\mathrm{Mn}$ and negatively correlated with As (Table 1). The higher concentration of $\mathrm{Cu}$ in the tin mining pond water as compared with literatures agrees with the findings of other researcher viz., [18], [38], [40].

Cadmium (Cd): The mean concentrations of Cadmium in the tin mine pond water was $1.03 \pm 0.21 \mathrm{mg} / \mathrm{L}$. In both the tin mining pond water studied the value were comparatively higher than $0.07 \pm 0.02 \mathrm{mg} / \mathrm{L}$ reported by Chopra and Pathak, [38] and the values agree with the findings of Boamponisem [41]. Considering the toxicity of $\mathrm{Cd}$ however, this study recorded a lower value compared with the study carried by Henry, [21], on one of the ex-mine ponds in Jos - South Plateau State. The high concentration of cadmium is said to be attributed to the large scale mining activity that took place and still going on within the vicinity in a small scale. Similar studies on irrigation water quality in Nigeria and abroad have reported slightly higher concentrations of Cadmium [42]. The concentration of $\mathrm{Cd}$ recorded in this analysis is above [37], [43] prescribed limits of 0.01 and $0.005 \mathrm{mg} / \mathrm{L}$, respectively. The Cd content in the water show significant correlation with other heavy metals and display positive correlation with arsenic $(\mathrm{P}>0.05)$ as presented in (Table 1).

TABLE 1: PEARSON’s CORRELATION COEFFICIENT MATRIX (MEAN) HEAVY METALS IN MINING POND WATER

\begin{tabular}{|c|c|c|c|c|c|c|c|}
\hline & $\mathrm{Pb}$ & $\mathrm{Cu}$ & $\mathrm{Cd}$ & $\mathrm{Zn}$ & $\mathrm{Cr}$ & Mn & As \\
\hline $\mathrm{Pb}$ & 1.000 & & & & & & \\
\hline $\mathrm{Cu}$ & 0.454 & 1.000 & & & & & \\
\hline $\mathrm{Cd}$ & 0.563 & 0.992 & 1.000 & & & & \\
\hline $\mathrm{Zn}$ & 0.261 & 0.300 & 0.315 & 1.000 & & & \\
\hline $\mathrm{Cr}$ & -0.725 & -0.363 & -0.440 & 0.453 & 1.000 & & \\
\hline $\mathrm{Mn}$ & -0.478 & 0.565 & 0.456 & 0.030 & 0.294 & 1.000 & \\
\hline As & 0.291 & -0.670 & -0.580 & -0.413 & -0.399 & -0.921 & 1.000 \\
\hline
\end{tabular}

Zinc (Zn): The mean concentration of $\mathrm{Zn}$ in mine pond water was $0.749 \pm 0.31 \mathrm{mg} / \mathrm{L}$. The mean value of $\mathrm{Zn}$ is quite high in both sites, compared FAO/WHO [37] prescribed standard for irrigation water. Related studies on irrigation water in Burkina Fasso, reported a mean concentration of $0.034 \mathrm{mg} / \mathrm{L}$ in groundwater [44], which is lower than the values recorded in this work. Similarly, Lente et al. also reported a mean concentration of $0.14 \mathrm{mg} / \mathrm{L}$ zinc in irrigation water in Accra, Ghana, which is in agreement with the values obtained in this study [45]. The concentration range of $\mathrm{Zn}, 0.34-1.39 \mathrm{mg} / \mathrm{L}$ were reported in different sources of irrigation water in Lahore, Pakistan [18]. The high concentrations of zinc recorded in this study could be due to weathering of geological materials and possibly small scale mining and runoff from farms treated with agrochemicals containing $\mathrm{Zn}$ [23].

Chromiun $(\mathbf{C r})$ : The mean concentration of chromium in the tin mine pond water was $0.35 \pm 0.3 \mathrm{mg} / \mathrm{L}$. The concentration of $\mathrm{Cr}$ in the tin mining pond water corroborated with the findings reported on similar work in Lahore, Pakistan [18], and the reported $0.38 \mathrm{mg} / \mathrm{L}$ in exmining pond in Plateau State [21]. Though the tin mining pond water showed higher $\mathrm{Cr}$ concentration compared to the prescribed standard limit by WHO/FAO and USEPA, the $\mathrm{Cr}$ concentration in the studied areas was lower compared to the $2.72-14.04 \mathrm{mg} / \mathrm{L}$ and $1.05 \mathrm{mg} / \mathrm{L}$ reported by Brar [45], [42], respectively. Statistically, there was significant difference $\mathrm{Cr}$ in at $95 \%$ confidence limit.

Manganese (Mn): The mean concentration of was $0.50 \pm$ $0.1 \mathrm{mg} / \mathrm{L}$ in the tin mine pond waters, $\mathrm{Mn}$ concentration was higher than the prescribed standards irrespective of the pond water studied. Similar reported high mean concentration of $\mathrm{Mn} 1.50 \pm 0.1 \mathrm{mg} / \mathrm{L}$ in sewage water used for irrigation in Asansol, West Bengal [42]. The Mn concentration tin mining pond water it is negatively correlated with As. ( $p$ $>0.05$ ). The high levels of Mn observed in the water can be attributed to anthropogenic activities, particularly large scale mining and the activities of motorist that took place within the area. Mining in general is known to have an influence on the flux of metals from geological materials to the hydrosphere through dissolution of minerals [46]. Manganese concentration in mining pond water used for irrigation of crops agrees with these findings [39], [47].

Arsenic (As): The mean of As in the tin mining pond waters in the study areas showed a concentration of $0.94 \pm 0.4 \mathrm{mg} / \mathrm{L}$. The concentration of As in this study is higher compared with $0.04 \mathrm{mg} / \mathrm{L}$ reported in sewage water used for irrigation in Northwest India [45]. Arsenic in water is mostly present as (As5+), but in anaerobic conditions, it is likely present as (As3+) WHO, [48]. Arsenic in drinking water is a global threat to health (United Nations International Children's Emergency Fund UNICEF, World Health Organization WHO [48]. It is considered by some researchers to have more serious health repercussions than any other environmental contaminant. The concentration reported in this work is very high compared to guideline value of $0.01 \mathrm{mg} / \mathrm{L}$ given to it by the World Health Organization [48]. 


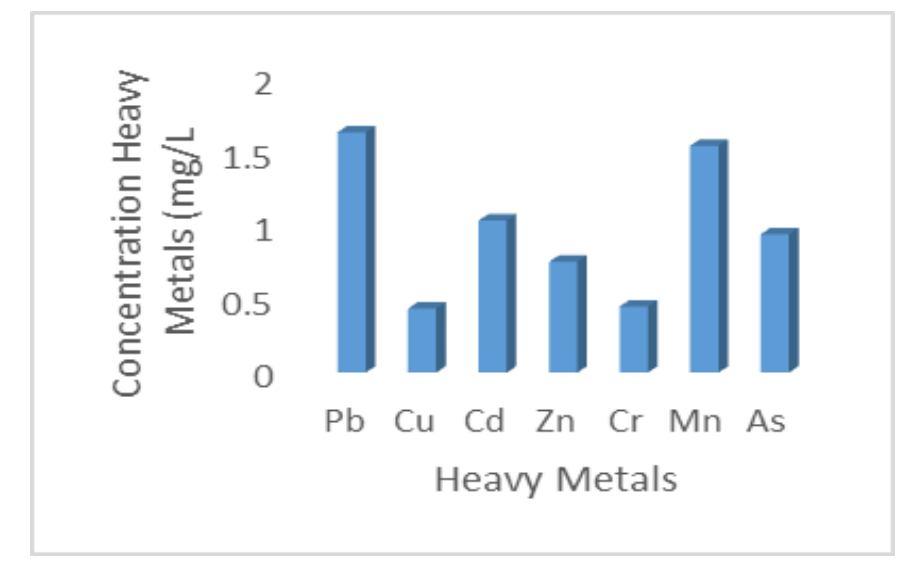

Fig. 3. Mean Concentration of Heavy metals in mine pond water (mg/L)

\section{B. Heavy metals in soil irrigated with tin mining pond Water}

Lead (Pb): The mean concentration of $\mathrm{Pb}$ obtained from the various sites was $83.0 \pm 13.3$. The result shows that the

concentration of $\mathrm{Pb}$ in both the study areas were slightly different and higher than the values obtained in Bokkos [23]. The concentration of $\mathrm{Pb}$ in the soil in respective of season and plots in the study areas is in the order of Doi $>$ Zawan > Little Ray Field > Ray field Resort. All the reported values are above the prescribed $50 \mathrm{mg} / \mathrm{kg}$ of soil WHO,[49] standard limits. The value of $\mathrm{Pb}$ obtained agree with that reported by Daniel et al. in Kassa Ropp BarkinLadi [50]. It is also revealed that $\mathrm{Pb}$ concentration in agricultural soil irrigated with contaminated water vary with the concentration reported in this study [51]. $\mathrm{Pb}$ in soil treated with mining pond water is positively correlated with $\mathrm{Cr}$ and As. The study showed the significant difference ( $\mathrm{p}$ $<0.05)$ in the $\mathrm{Pb}$ content of the treated soils collected in both seasons.

Copper $(\mathbf{C u})$ : The mean value of $\mathrm{Cu}$ in mining pond water treated soil was $22.5 \pm 9.64 \mathrm{mg} / \mathrm{kg}$, It is also observed that there is a significant different in the concentration of $\mathrm{Cu}$ in the sites studied. The $\mathrm{Cu}$ concentration of the irrigated soils is within the safe limit for cultivation. In it observed that $\mathrm{Cu}$ positively correlated with As. The metals concentration in both soil irrigation with mining pond water, corroborated with the findings [21].

Cadmium (Cd): The mean concentration of $\mathrm{Cd}$ in the mining pond water treated soil in both sites studied shows a value of $1.14 \pm 0.6 \mathrm{mg} / \mathrm{kg}$. The concentration obtained in this work for soil treated with tin mining pond water agrees with the $0.965 \mathrm{mg} / \mathrm{kg}$ reported by Ratul et al. [51] in agricultural soil irrigated with contaminated river water. Comparing with the safe limit of $\mathrm{Cd}$ in the soil, it is found that treated soils in the both season are within the prescribed standards of $3-6 \mathrm{mg} / \mathrm{kg}$ set by [48], [49], [52].

Cadmium concentration in soil was relatively high, $\mathrm{Cd}$ correlated positively $\mathrm{Cr}$ this may have been attributed to applications of fertilizers and other farming practices including used of pesticides. Generally, the high concentrations of metals in these areas could also be as a result of the tin mine activities, wastes dumped and metals availability in the earth crust. In this study $\mathrm{Cd}$ concentration in both irrigated soils are lower compared to the literature values $15.4 \pm 6.6 \mathrm{mg} / \mathrm{kg}$ and $3.54 \pm 0.6 \mathrm{mg} / \mathrm{kg}$ reported [18] [50].
Zinc ( $\mathbf{Z n ) : ~ T h e ~ m e a n ~ c o n c e n t r a t i o n ~ o f ~} \mathrm{Zn}$ in the mining pond water treated soil during was $77.7 \pm 6.3 \mathrm{mg} / \mathrm{kgfor}$ both sites. From the value of $\mathrm{Zn}$ content in the tin mining pond water irrigated soil, it is clear that the water has potential for the development of $\mathrm{Zn}$ enrichment. Both the soil samples analyzed has been found to be enriched with more $\mathrm{Zn}$ though within the safe limit of $200 \mathrm{mg} / \mathrm{kg}$ prescribed by USEPA and $300 \mathrm{mg} / \mathrm{kg}$ by WHO. The $\mathrm{Zn}$ concentration in the soil irrigated with tin mining pond water reported in this study is in agreement with wastewater irrigated soil concentrations published by Mahmood and Malik and reported concentration in agricultural soil irrigated with contaminated river water [51] but however, higher compared to the result of $3.9 \pm 0.1$ and $6.03 \pm 1.7 \mathrm{mg} / \mathrm{kg}$ reported Tukura et al. [35] and Lente et al. [40], respectively.

Chromium (Cr): The soil samples collected and analyzed exhibited the mean $\mathrm{Cr}$ concentration of $21.8 \pm 6.5$ $\mathrm{mg} / \mathrm{kg}$. The result reported in this study is in agreement with $22.9 \mathrm{mg} / \mathrm{kg}$ reported by Ghosh et al. [52] and $20.01 \pm 11.3 \mathrm{mg} / \mathrm{kg}$ [18]. The concentration obtained even though high, is lower than the value $54.2 \mathrm{mg} / \mathrm{kg}$ reported by Daniel et al. [53] in Kassa Ropp for similar tin mining soil and $69.75 \mathrm{mg} / \mathrm{kg}$ reported by Ratul et al. [40] in agricultural soil irrigated with contaminated river water. However, the low value may be as attributed to leaching of metals beneath the soil. The $\mathrm{Cr}$ concentration in soil of both plots irrespective of sites are within the $150 \mathrm{mg} / \mathrm{kg}$ safe limit of EU standard [54].

Manganese (Mn): The soil irrigated with mining pond water during had a mean of $16.8 \pm 1.9 \mathrm{mg} / \mathrm{kg}$. Variation of mean Mn concentration in soil is not high as the order was Zawan > Ray field Resort > Doi > Little Ray Field. The high $\mathrm{Mn}$ concentration may be attributed to accumulation washing from different places such as roads, ashes from burn vegetation washed down by rainfall.

Arsenic (As): The mean concentration of As in mining pond water treated soil was $135 \pm 56 \mathrm{mg} / \mathrm{kg}$. The values showed that there is accumulation of As in the soil as a result industrial wastes and pesticide applications which might increase concentrations. The As level in the irrigated soils was far above the safe limit of $20 \mathrm{mg} / \mathrm{kg}$ prescribed by WHO, for cultivation. As, show positive correlation with $\mathrm{Mn} \mathrm{Cr}$ and $\mathrm{Pb}$. Naturally elevated levels of arsenic in soils may be associated with geological substrata such as sulfide ores therefore, anthropogenically contaminated soils can have several concentrations of arsenic [55]. Arsenic concentrations of up to $27000 \mathrm{mg} / \mathrm{kg}$ were reported in soils contaminated with mine or smelter wastes [56]. Soil on agricultural land treated with arsenical pesticides may retain substantial amounts of arsenic. Mean total arsenic concentrations of $50-60 \mathrm{mg} / \mathrm{kg}$ have been recorded for agricultural soils treated with arsenical pesticides [57]. 
TABLE 2. PEARSON's CORRELATION COEFFICIENT MATRIX (MEAN) HEAVy METALS CONTENT IN SOIL

\begin{tabular}{cccccccc}
\multicolumn{7}{c}{ METALS CONTENT IN SOIL } \\
\hline & $\mathrm{Pb}$ & $\mathrm{Cu}$ & $\mathrm{Cd}$ & $\mathrm{Zn}$ & $\mathrm{Cr}$ & $\mathrm{Mn}$ & $\mathrm{As}$ \\
$\mathrm{Pb}$ & 1.000 & & & & & & \\
$\mathrm{Cu}$ & -0.798 & 1.000 & & & & & \\
$\mathrm{Cd}$ & 0.138 & -0.489 & 1.000 & & & & \\
$\mathrm{Zn}$ & 0.369 & 0.140 & 0.156 & 1.000 & & & \\
$\mathrm{Cr}$ & 0.728 & 0.213 & 0.735 & 0.112 & 1.000 & & \\
$\mathrm{Mn}$ & -0.371 & -0.068 & -0.280 & -0.992 & -0.199 & 1.000 & \\
$\mathrm{As}$ & 0.823 & 0.996 & -0.448 & 0.230 & 0.239 & -0.161 & 1.000 \\
\hline
\end{tabular}

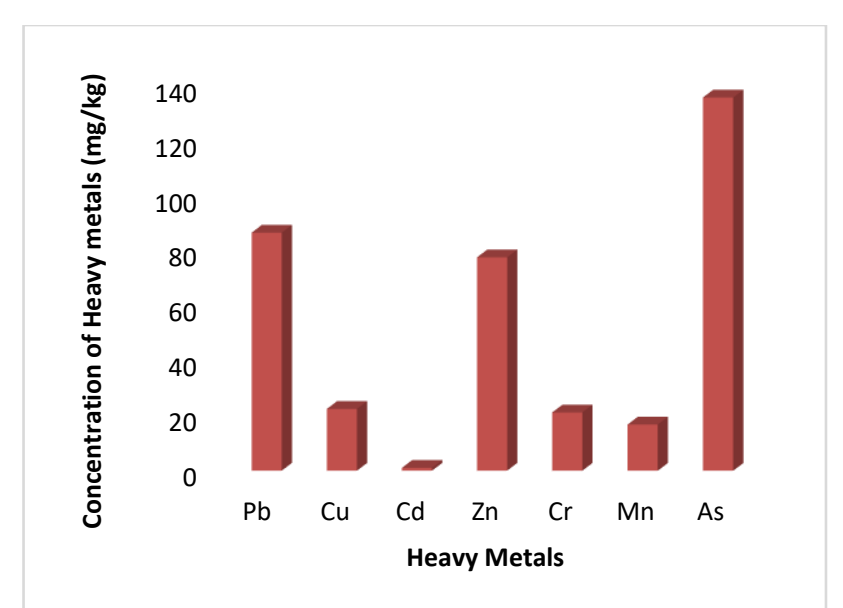

Fig. 4. Mean Concentration of heavy metals in soil irrigated with mined Pond Water $(\mathrm{mg} / \mathrm{kg})$.

\section{Heavy Metals Accumulation in Vegetables Cultivated with Tin Mining Pond Water Tomato}

Table 3 shows that the concentration of $\mathrm{Pb}$ in tomatoes $0.39 \pm 0.1 \mathrm{mg} / \mathrm{kg}$ he values obtained are similar to the value $0.26-0.70 \mathrm{mg} / \mathrm{kg}$ by Mahmood and Malik. $\mathrm{Pb}$ in tomato showed concentrations above maximum permissible limit and standard value. Nassar, also observed high levels of $\mathrm{Pb}$ $(2.40 \pm 0.99) \mathrm{mg} / \mathrm{kg}$ and $\mathrm{Cd}(0.25 \pm 0.11) \mathrm{mg} / \mathrm{kg}$ in wastewater irrigated tomatoes in Egypt [58]. Al-Jaboobi et al. reported higher concentration of $10.75 \mathrm{mg} / \mathrm{kg}$ in wastewater irrigated tomatoes [59].

The mean concentration of Arsenic in tomatoes was $0.22 \pm 0.03 \mathrm{mg} / \mathrm{kg}$. This concentration is high compared to $0.06 \pm 0.02 \mathrm{mg} / \mathrm{kg}$ [44] and lower than $0.62 \pm 0.19 \mathrm{mg} / \mathrm{kg}$ findings by Duressa and Leta [60]. The high value of Arsenic in Jos might be due the closeness of the mining pond to leather/tannin Company who equally uses the water and also discharges its influents close to the pond. The mean of $\mathrm{Cr}$ were also high in the study areas, $0.13 \pm 0.01 \mathrm{mg} / \mathrm{kg}$ seasons. The high value of $\mathrm{Cr}$ obtained in this study is lower compared to $0.66 \mathrm{mg} / \mathrm{kg}$ reported by Orish et al [61] and $2.97 \mathrm{mg} / \mathrm{kg}$ by Yadav et al. [62], in a similar mining sites. $\mathrm{Cd}$ was a little high in some site this might have been due washing by runoff water from the immediate vicinity since several anthropogenic processes took place and are still occurring in small scale by illegal miners. This is agree with the $0.12 \mathrm{mg} / \mathrm{L}$ reported by Saglam [63] on the study of vegetables in dry - and - season in Southern Turkey. The high concentrations of some of these metals in the areas could be as a result of the closeness of the mining ponds to major traffic highways The order of metal concentration in tomatoes in this work is; $\mathrm{Mn}>\mathrm{Zn}>\mathrm{Pb}>\mathrm{Cu}>\mathrm{Cr}>\mathrm{As}>$ $\mathrm{Cd}$. Heavy metal accumulation in tomato due to long-term wastewater irrigation was also highlighted by Sharma [64].

\section{Garden egg}

The mean concentrations of each heavy metals for garden egg in the three sites shows that $\mathrm{Pb}(0.40), \mathrm{Cr}(0.13)$ and $\mathrm{Mn}$ $(0.83) \mathrm{mg} / \mathrm{kg}$ were higher than the standard permissible limit FAO/WHO in both study sites. The order of heavy metals accumulation in garden egg was $\mathrm{Zn}>\mathrm{Pb}>\mathrm{Mn}>\mathrm{Cr}>\mathrm{Cu}>$ As $>\mathrm{Cd}$. Pearson's correlation shows that in garden egg $\mathrm{Pb}$ is positively correlated with $\mathrm{As}$, while $\mathrm{Cu}$ is positively correlated with $\mathrm{Zn}, \mathrm{Cr}$, Fe and negatively correlated with $\mathrm{Mn}$. The results obtained in this study were similar to the reported studies some scholars [66] [65]. Tukura et al., reported high levels of $\mathrm{Zn}(1.60)$ and $\mathrm{Pb}(0.36) \mathrm{mg} / \mathrm{kg}$.

\section{Pepper}

The mean concentration of $\mathrm{Pb} \quad(0.177 \pm 0.01), \mathrm{Cr}$ $(0.132 \pm 0.03), \mathrm{Cd}(0.007 \pm 0.01)$ and $\mathrm{Mn}(0.253 \pm 0.03) \mathrm{mg} / \mathrm{kg}$ were obtained in this study. All metals show order of concentration $\mathrm{Cu}>\mathrm{Zn}>\mathrm{Mn}>\mathrm{Pb}>\mathrm{Cr}>\mathrm{As}>\mathrm{Cd}$. The concentrations of $\mathrm{Mn}, \mathrm{Cr}, \mathrm{Pb}$ and $\mathrm{Cd}$ in pepper have crossed the prescribed safe value of WHO/FAO [67] and EU standard, respectively but within the limit of Indian standard. The high concentration of these metals in pepper might be attributed to high level of pesticides and fertilizer on farmland for better yield of crops. Duressa and Leta, $1.15 \pm 0.29 \mathrm{mg} / \mathrm{kg}$ accumulation of $\mathrm{Cd}$ in pepper. Dorcas et al. (2016); Jolly et al. [68]; also reported high concentration of heavy metals in pepper irrigated with wastewater from mines and industrial discharges to soils.

\begin{tabular}{ccccccc}
\multicolumn{6}{c}{ TABLE 3. MEAN } & \multicolumn{6}{c}{ SD OF HEAVY Metal ConCENTRATION IN VEGETABLES IRRIGATED Tin Mine WATER (MG/KG) } \\
\hline Metals & Tomato & Garden Egg & Pepper & Cabbage & Carrot & Spinach \\
\hline $\mathrm{Pb}$ & $0.392 \pm 0.07$ & $0.316 \pm 0.01$ & $0.177 \pm 0.01$ & $0.271 \pm 0.05$ & $0.545 \pm 0.03$ & $0.376 \pm 0.03$ \\
$\mathrm{Cu}$ & $0.077 \pm 0.01$ & $0.085 \pm 0.03$ & $0.440 \pm 0.12$ & $0.073 \pm 0.01$ & $0.155 \pm 0.02$ & $0.748 \pm 0.02$ \\
$\mathrm{Cd}$ & $0.019 \pm 0.01$ & $0.006 \pm 0.01$ & $0.007 \pm 0.01$ & $0.011 \pm 0.01$ & $0.013 \pm 0.10$ & $0.005 \pm 0.00$ \\
$\mathrm{Zn}$ & $0.619 \pm 0.17$ & $0.349 \pm 0.03$ & $0.415 \pm 0.02$ & $0.264 \pm 0.05$ & $0.915 \pm 0.06$ & $0.555 \pm 0.03$ \\
$\mathrm{Cr}$ & $0.131 \pm 0.01$ & $0.114 \pm 0.01$ & $0.132 \pm 0.03$ & $0.089 \pm 0.03$ & $0.158 \pm 0.04$ & $0.115 \pm 0.00$ \\
$\mathrm{Mn}$ & $0.184 \pm 0.01$ & $0.186 \pm 0.01$ & $0.253 \pm 0.03$ & $0.164 \pm 0.02$ & $0.682 \pm 0.04$ & $0.162 \pm 0.01$ \\
\hline $\mathrm{As}$ & $0.215 \pm 0.03$ & $0.056 \pm 0.01$ & $0.032 \pm 0.002$ & $0.043 \pm 0.04$ & $0.245 \pm 0.05$ & $0.050 \pm 0.01$ \\
\hline
\end{tabular}




\section{Cabbage}

The mean concentration of $\mathrm{Pb}$ in cabbage from the study sites was $0.27 \pm 0.05 \mathrm{mg} / \mathrm{Kg}$ while, $\mathrm{Cd}$, As and $\mathrm{Cr}$ were $0.011 \pm 0.01,0.043 \pm 0.04$ and $0.089 \pm 0.03 \mathrm{mg} / \mathrm{kg}$, respectively. $\mathrm{Cd}$ was also slightly high with range of though lower than $0.22 \pm 0.2 \mathrm{mg} / \mathrm{kg}$ reported by Benti [69], $1.61 \pm 0.2 \mathrm{mg} / \mathrm{kg}$ by Abdul et al. [70] and $6.25 \pm 1.2 \mathrm{mg} / \mathrm{kg}$ Kumar and Seema [71]. Similar studies conducted and show the same trend of metal behavior in cabbage [58]. The order of concentration of the heavy metals in dry - and - rainy seasons is $\mathrm{Pb}>\mathrm{Zn}$ $>\mathrm{Mn}>\mathrm{Cr}>\mathrm{Cu}>\mathrm{As}>\mathrm{Cd}$.

The high levels of these metals in this vegetable might be as a result of the use of pesticides and herbicides and irrigated with tin mine water [72]. This also agrees with the fact that, the application of large volumes of partially treated or untreated wastewater in some parts of Africa has adversely affected both surface water bodies and the urban and peri-urban farmers using these water bodies as sources of irrigation [73].

\section{Carrot}

The mean of heavy metals in the carrot analyzed from the sites studied showed that the concentrations are higher in all the field except for metals $\mathrm{Cu}$ and $\mathrm{Zn}$. All studied metals crossed the safe limit of FAO/WHO standards and EU standard. Carrots from all the farms were not safe for human consumption as their concentrations were above the maximum permissible limit, $0.30 \mathrm{mg} / \mathrm{kg}$. The mean concentrations of all the heavy metals in carrot ranged from $0.013-0.915 \mathrm{mg} / \mathrm{kg}$ with $\mathrm{Mn}$ having a high concentration of $0.682 \pm 0.04 \mathrm{mg} / \mathrm{kg}$. The studied metals are in descending order of $\mathrm{Zn}>\mathrm{Mn}>\mathrm{Pb}>\mathrm{As}>\mathrm{Cr}>\mathrm{Cu}>\mathrm{Cd}$. Dorcas et al., showed that cadmium $(\mathrm{Cd})$ had mean concentration of 0.36 $\mathrm{mg} / \mathrm{kg}$ in carrots higher than $0.13 \mathrm{mg} / \mathrm{kg}$ recorded in this work[57]. Higher values of these metals were also reported by Mafuyai et al., in his studies on mining pond water in Bokkos, Nigeria [23].

\section{Spinach}

The concentration of all the metal studied in all sites were found to have high metals in spinach but others show lower values. The $\mathrm{Pb}$ has mean concentration of $0.399 \mathrm{mg} / \mathrm{kg}$, while $\mathrm{Cr}$ has $(0.115 \pm 0.00), \mathrm{Mn}(0.162 \pm 0.01), \mathrm{Cd} 0.005 \pm 0.00$ and As $(0.055 \pm 0.01 \mathrm{mg} / \mathrm{kg}$. Comparing with the prescribed standards it is found that $\mathrm{Pb}, \mathrm{Cr}, \mathrm{As}, \mathrm{Mn}$ and $\mathrm{Cd}$ concentrations in spinach crossed the safe limit of WHO/FAO and EU However, the major sources of this contamination may be due to the mining pond water used in irrigation, solid waste disposal, sludge applications, vehicular exhaust and agrochemicals. Excessive accumulation of heavy metals in agricultural soils through the use of agrochemicals and by other sources may lead to elevated heavy metal up-take by vegetables and thus affect food quality and safety [74]. The variations in heavy metal concentrations in vegetables of the same site may be ascribed to the differences in their morphology and physiology for heavy metal uptake, exclusion, accumulation and retention [75].

The tin mining pond water used for irrigation purposes may route the uptake of heavy metals from roots to the edible parts of the vegetables. Industrial and traffic emission, burning of fossil fuel, discharge of $\mathrm{Pb}^{2+}$ storage batteries, sewage water, and paints/pigment may be the main sources of $\mathrm{Pb} 2+$ while $\mathrm{Cr} 2+$ is discharged from electroplating and pigments/paints industries, textile mills and tanneries in the city of Jos. In human body $\mathrm{Cd} 2+$ induces the gastrointestinal problem and severe toxic effects on different body parts like the kidney, liver, ovaries, testis, nervous system and cardiovascular system.

\section{Transfer efficiency (TF) of heavy metals from soil to vegetables}

Transfer efficiency or transfer factor (TF) is an index used to assess the mobility of metal from soil to plant which is one of the key components of human exposure to metals through the food chain. The TF values of $\mathrm{Pb}, \mathrm{Cu}, \mathrm{Cd}, \mathrm{Zn}$, $\mathrm{Cr}, \mathrm{Mn}$ and As for various vegetables vary greatly and the transfer factor of different heavy metals in cultivated vegetables in respect with irrigated soil and vegetables showed that $\mathrm{Cd}$ was highest in all vegetables studied with $\mathrm{Zn}$ in Pepper. Table 4 summarizes the transfer efficiency of heavy metals in vegetables from the study area. The values of transfer factor ranged from $\mathrm{Pb}(0.005-0.011), \mathrm{Cu}(0.005$ - 0.023), Cd (0.010 - 0.084), Zn (0.02 - 0.041), Cr (0.007 $0.024), \mathrm{Mn}(0.011-0.058)$ and As (0.00 - 0.001).Among the tin mining pond water irrigated fields' vegetables, maximum TFCd (0.084) found in spinach and the lowest in TFCr (0.018). The rank of transfer factor the heavy metals in vegetables appeared as TF:

$$
\mathrm{Cd}>\mathrm{Mn}>\mathrm{Zn}>\mathrm{Cr}>\mathrm{Cu}>\mathrm{As}>\mathrm{Pb}
$$

\begin{tabular}{ccccccc}
\multicolumn{6}{c}{ TABLE } & TRANSFER FACTOR OF HEAVy MeTAls FROM SOIL TO VEGETABLES GROWN \\
\hline Metals & Tomatoes & Garden Egg & Pepper & Cabbage & Carrot & Spinach \\
\hline $\mathrm{TF}_{\mathrm{Pb}}$ & 0.005 & 0.010 & 0.006 & 0.011 & 0.007 & 0.001 \\
$\mathrm{TF}_{\mathrm{Cu}}$ & 0.005 & 0.023 & 0.015 & 0.021 & 0.011 & 0.017 \\
$\mathrm{TF}_{\mathrm{Cd}}$ & 0.036 & 0.027 & 0.067 & 0.010 & 0.056 & 0.084 \\
$\mathrm{TF}_{\mathrm{Zn}}$ & 0.020 & 0.037 & 0.021 & 0.041 & 0.041 & 0.029 \\
$\mathrm{TF}_{\mathrm{Cr}}$ & 0.018 & 0.024 & 0.011 & 0.007 & 0.013 & 0.015 \\
$\mathrm{TF}_{\mathrm{Mn}}$ & 0.011 & 0.014 & 0.015 & 0.022 & 0.022 & 0.058 \\
$\mathrm{TF}_{\mathrm{As}}$ & 0.007 & $\mathrm{BDL}$ & $\mathrm{BDL}$ & $\mathrm{BDL}$ & 0.002 & BDL \\
\hline
\end{tabular}

But all the transfer factor values are $<1$, which indicates the vegetables are exclude from the uptake of heavy metals. The transfer factor in of heavy metals in each of the vegetable studied is the trend of:

Tamatoes: $\mathrm{Cd}>\mathrm{Zn}>\mathrm{Cr}>\mathrm{Mn}>\mathrm{As}>\mathrm{Pb}=\mathrm{As}$,

Garden Egg: $\mathrm{Zn}>\mathrm{Cd}>\mathrm{Cr}>\mathrm{Cu}>\mathrm{Mn}>\mathrm{Pb}>\mathrm{As}$,
Pepper: $\mathrm{Cd}>\mathrm{Zn}>\mathrm{Mn}=\mathrm{Cu}>\mathrm{Cr}>\mathrm{Pb}>\mathrm{As}$, Cabbage: $\mathrm{Zn}>\mathrm{Mn}>\mathrm{Cu}>\mathrm{Pb}>\mathrm{Cd}>\mathrm{Cr}>\mathrm{As}$, Carrot: $\mathrm{Cd}>\mathrm{Zn}>\mathrm{Mn}>\mathrm{Cr}>\mathrm{Cu}>\mathrm{Pb}>\mathrm{As}$

Spinach: $\mathrm{Cd}>\mathrm{Mn}>\mathrm{Zn}>\mathrm{Cu}>\mathrm{Cr}>\mathrm{Pb}>$ As.

The transfer factor of irrigated soil to cultivated vegetables also studied by Ibrahim et al. [76] reported the 
TF of the heavy metals from soils to lettuce in his study to be $\mathrm{Fe}$ (0.72), $\mathrm{Zn}(0.71) \mathrm{Cu}$ (0.67), $\mathrm{Cd}(0.64), \mathrm{Cr}(0.43)$ and $\mathrm{Pb}(0.42)$. Tukura et al. in his findings, showed that the potential for metal uptake from soil by vegetable varied in decreasing order of $\mathrm{Cd}>\mathrm{Zn}>\mathrm{Ni}>\mathrm{Mn}>\mathrm{Cu}>\mathrm{Pb}[40]$.

The relative efficiency of plants to accumulate heavy metals in their edible and non-edible parts is influence by $\mathrm{pH}$, bioavailability metals and the transport of heavy metals in the soil. Heavy metals mobility decreases with increase in soil $\mathrm{pH}$ due the precipitation of hydroxides, carbonates or the formation of insoluble complexes [77].

\section{E. Daily intake of metals (DIM)}

The consumption of vegetables irrigated with tin mining pond water show highest daily intake in $\mathrm{Cd}$ in tomato, carrot, spinach and pepper. The highest daily intake of $\mathrm{Zn}$ occurs through the consumption of garden egg and cabbage in the study sites (Table 5). The high consumption of $\mathrm{Mn}$ was also observed in cabbage and spinach among other vegetables. The estimated daily intake (DIM) of heavy metals from vegetables irrigated with tin mining pond water were in the order:

$$
\mathrm{Cd}>\mathrm{Zn}>\mathrm{Mn}>\mathrm{Cr}>\mathrm{Cu}>\mathrm{Pb}>\mathrm{As} \text {. }
$$

TABLE 5. DAILY INTAKE OF HEAVY METAL (ON DRY WEIGHT BASIS) FOR HEAVY METAL DUE CONSUMPTION OF VEGETABLES

\begin{tabular}{cccccccc}
\hline Vegetables & $\mathbf{P b}$ & $\mathbf{C u}$ & $\mathbf{C d}$ & $\mathbf{Z n}$ & $\mathbf{C r}$ & Mn & As \\
\hline Tomato & 0.00020 & $4 \mathrm{E}-05$ & $1 \mathrm{E}-05$ & 0.00030 & $6.87 \mathrm{E}-05$ & $9.7 \mathrm{E}-05$ & 0.00011 \\
Garden Egg & 0.00020 & $4.5 \mathrm{E}-05$ & $3.1 \mathrm{E}-06$ & 0.00018 & $5.98 \mathrm{E}-05$ & $9.8 \mathrm{E}-05$ & $2.9 \mathrm{E}-05$ \\
Pepper & $9.3 \mathrm{E}-05$ & 0.00023 & $3.1 \mathrm{E}-06$ & 0.00022 & $6.92 \mathrm{E}-05$ & 0.00013 & $1.7 \mathrm{E}-05$ \\
Cabbage & 0.00014 & $3.8 \mathrm{E}-05$ & $5.8 \mathrm{E}-06$ & 0.00014 & $4.67 \mathrm{E}-05$ & $8.8 \mathrm{E}-05$ & $2.3 \mathrm{E}-05$ \\
Carrot & 0.28591 & 0.81313 & 0.06820 & 0.00480 & 0.00829 & 0.03578 & 0.00013 \\
Spinach & 0.00020 & 0.00039 & $2.62 \mathrm{E}-04$ & 0.00029 & $6.03 \mathrm{E}-05$ & $8.5 \mathrm{E}-05$ & $2.6 \mathrm{E}-05$ \\
\hline
\end{tabular}

From the values of DIM of metals it is quite clear that among consumer of the cultivated vegetables in the study areas are unsafe as heavy metals bioaccumalate in a biota. The daily heavy metal intake through vegetable consumption in this study is less than RfD limits; for $\mathrm{Pb}$ (0.0035), Mn (0.033), Cr (1.5), Cd (0.001), Zn (0.30), Cu (0.04), Fe (0.700) and As (0.0003) $\mathrm{mg} / \mathrm{Kg}$. day, respectively set by the US EPA, Integrated Risk Information System (IRIS) which will not poses human health problem. All DIM values of metals showed significant difference in all metals. Similar kinds of finding were observed [61] on metal concentrations increased in the order $\mathrm{Ni}>\mathrm{Zn}>\mathrm{Cu}>\mathrm{Cr}>$ $\mathrm{Se}>\mathrm{Cd}$ and ranged from $0.89-74.02 \mathrm{mg} / \mathrm{kg}$. The values of DIM in this study are collaborated with the findings of DIM for $\mathrm{Cu}, \mathrm{Ni}, \mathrm{Cd}, \mathrm{Cr}, \mathrm{Pb}$ and $\mathrm{Zn}$ ranged from $1.8 \times 10-3$ $7.5 \times 10-3,8.1 \times 10-4-2.5 \times 10-3,4.9 \times 10-5-1.4 \times 10-4,1.4 \times 10-$ 4- $1.2 \times 10-3,1.1 \times 10-3-2.8 \times 10-3$ and $6.7 \times 10-3-1.4 \times 10-2$ $\mathrm{mg} / \mathrm{kg} /$ day, respectively, [50] for Trend of the metal intake by all vegetables are: $\mathrm{Zn}>\mathrm{Cu}>\mathrm{Pb}>\mathrm{Ni}>\mathrm{Cr}>\mathrm{Cd}$. Trend of health risk of heavy metals for the consumption of vegetables are $\mathrm{Pb}>\mathrm{Cu}>\mathrm{Cd}>\mathrm{Ni}>\mathrm{Zn}>\mathrm{Cr}$.

\section{F. $\quad$ Health risk index (HRI)}

Table 6 summarizes the health risk indexes of heavy metals in vegetables from the study area. It ranges from The HRI values of $\mathrm{Pb}$ were higher in tomato, garden egg, carrot and spinach. As was high in garden egg and cabbage, while other metals show negligible HRI in the vegetables grown in both fields under consideration of health risk. The HRI values of $\mathrm{Cd}$ (2.293) in carrot and As (0.979) in garden egg consumed were highest in the vegetables which have the likelihood of posing substantial HRI. The HRI in terms of the vegetables and heavy metals in the studied vegetables is in order:

Carrot $>$ Garden Egg $>$ Tomatoes $>$ Cabbage $>$ Pepper $>$ Spinach and $\mathrm{Cd}>\mathrm{As}>\mathrm{Pb}>\mathrm{Mn}>\mathrm{Cu}>\mathrm{Zn}>\mathrm{Cr}$

\begin{tabular}{|c|c|c|c|c|c|c|c|}
\hline Vegetables & $\mathrm{Pb}$ & $\mathrm{Cu}$ & $\mathrm{Cd}$ & $\mathrm{Zn}$ & $\mathrm{Cr}$ & $\mathrm{Mn}$ & As \\
\hline Tomato & 0.8714 & 0.0010 & 0.0100 & 0.0010 & 0.0000 & 0.0241 & 0.376 \\
\hline Garden Egg & 0.7571 & 0.0011 & 0.0031 & 0.0006 & 0.0000 & 0.0244 & 0.979 \\
\hline Pepper & 0.2653 & 0.0058 & 0.0031 & 0.0007 & 0.0000 & 0.0332 & 0.560 \\
\hline Cabbage & 0.0406 & 0.0010 & 0.0058 & 0.0005 & 0.0000 & 0.0220 & 0.756 \\
\hline Carrot & 0.5169 & 0.0020 & 2.2930 & 0.0016 & 0.0001 & 0.0894 & 0.428 \\
\hline Spinach & 0.0564 & 0.0098 & 0.0026 & 0.0010 & 0.0000 & 0.0212 & 0.087 \\
\hline
\end{tabular}

All HRI values of metals showed significant difference in all metals except $\mathrm{Cr}$. Orish et al. also show the HRI values of heavy metals for adults from vegetable consumption to be in this decreasing order $\mathrm{Ni}>\mathrm{Cu}>\mathrm{Zn}>\mathrm{Cd}>\mathrm{Se}>\mathrm{Cr}$ [61]. Kumar and Seema reported the human health risk index calculated for metals of vegetables for adult and its rank appeared as $\mathrm{Pb}>\mathrm{Cd}>\mathrm{Mn}>\mathrm{Ni}>\mathrm{Cu}>\mathrm{Cr}$ in case of vegetable grown with sewage water at all locations [71]. The trend of HRI for vegetables grown at the locations was in the order $\mathrm{Cd}>\mathrm{Mn}>\mathrm{Ni}>\mathrm{Pb}>\mathrm{Cu}>\mathrm{Cr}$. The findings of this study regarding DIM and HRI suggest that the consumption of vegetables grown in well water and mining pond water irrigated soils is nearly free of risks while others are at the risk of the local population (all the HRI values are 
less than (1) except $\mathrm{Cd}$ in Carrot), but bioaccumulation of this metals can be detrimental as there are also other sources of heavy metal exposures such as dust inhalation, dermal contact and ingestion (for children) of metal-contaminated soils, which were not included in this study [78].

\section{CONCLUSION}

The continuous tin mining pond water irrigation has changed the soil physicochemical characteristics and has led to heavy metal uptake by food crop, predominantly vegetables. The present study revealed that tin mining pond water irrigated soil and food crops grown at the agricultural field were moderately enriched with $\mathrm{Pb}, \mathrm{Cd}, \mathrm{Mn}, \mathrm{As}$, and $\mathrm{Cr}$. In vegetables the extent of heavy metals enrichment was in the order of $\mathrm{Cd}>\mathrm{Mn}>\mathrm{Zn}>\mathrm{Cr}>\mathrm{Cu}>\mathrm{As}>\mathrm{Pb}$. The transfer factor values were $<1$, which indicates the vegetables are exclude from the uptake of heavy metals. The daily heavy metal intake through vegetable consumption in this study is less than RfD limits. Though, the values of DIM of metals were less it is evident that consumer of the cultivated vegetables in the study areas are unsafe as heavy metals bioaccumalate in a biota. The research also revealed that vegetables have a higher capability to accumulate the heavy metals from soil. The HRI indicated that vegetables grown with tin mining pond water are free from any risk; however, carrot and garden egg pose a serious health risk, particularly with $\mathrm{Cd}^{2+}$ and $\mathrm{AS}^{2+}$. Therefore, long-term use of tin mining pond water for irrigation purpose may lead to the severe risk to consumer's health. It is paramount that urgent attention is required for the implementation of proper means to monitor and regulate the industrial and municipal effluents.

\section{RECOMMENDATIONS}

Taking the health risks in diet as a result of high level of heavy metals in vegetables, the maximum allowable levels of these metals in vegetables should not exceed levels that reflect good agriculture practices. Farmers should be educated on the problems associated with excessive usage of fertilizers and other chemicals, as well as irrigating the vegetables with waste water and the need to grow vegetables with safe levels of heavy metals. The data generated must be used as baseline wastewater quality framework to serve as a basis for monitoring irrigation water quality in urban areas of Rewa to ensure safety.

The high HQ of $\mathrm{Pb}$ suggested that the consumption of Spinach grown in waste water irrigated site of Naubasta is not free of risks. Responsible agencies should carry out public health education within the consumption area to sensitive the general public on the potential effects of indiscriminate disposal of waste and the potential health hazards associated with the consumption of vegetables cultivated with wastewater. Measures must be taken to reduce heavy metal pollution and nutrient loading of irrigation water and soils to protect the safety of both farmers and consumers.

\section{ACKNOWLEDGEMENTS}

We would like to acknowledge Prof. I.S. Eneji, Prof. R. Sha'Ato and Dr. L.A. Nnamonu who were my PhD. Supervisors, thank you for mentoring me. The technical staff, Chemistry Department, University of Jos for helping and encouraging us during the laboratory analysis. Also our great thanks to Dr. N.M. Kamoh for assisting statistically in putting us through the statistical calculations. We also appreciate the University for their Collaboration and logistic support to monitor this study. Lastly, my wife Victoria Godwin, you are wonderful may the good God keep you.

\section{REFERENCES}

[1] G. Chauhan and U.K. Chauhan, (2014). Human health risk assessment of heavy metals via dietary intake of vegetables grown in wastewater irrigated area of Rewa, India. International Journal of Scientific and Research Publications, 4(9), pp. 1-9.

[2] A.O. Adegbulugbe. "Issues of Radioactive Waste Arising from Tin Mining Activities on the Jos Plateau" Paper presented to the Nigerian Nuclear Regulatory Authority, 2007.

[3] H. I. Ajaegbu, A. A. Adepetu, J.E. Ajakpo, V.C. Ihemegbulem, S.E Jumbo, J.A. Olaniyan, G.C. Okechukwu and K. Schoeneich, (1992) "Jos Plateau Environmental Excursion Guide" Jos Plateau Environmental Resources Development Programme (J.P.E.R.D.P.) Department of Geography, University of Durham., Durham, England.

[4] S. Koushik, A. Kalyan and G. Aniruddha. Assessment of Heavy Metal Contamination of Soil In and Around Open Cast Mines of Raniganj Area, India. Pp.45-69. 2012.

[5] S. Li, W. Liu, S. Gu, X. Cheng, Z. Xu, and Q.Zhang. Spatiotemporal dynamics of nutrients in the upper Han River basin, China. J. Hazard. Mater. 162(2), pp. 1340. 2009.

[6] D. Hinrichsen, and H. Tacio (2002). The coming fresh water crisis is already here. Finding the source: The linkages between population and water. Woodrow Wilson International Center for Scholars, Washington, DC, ESCP Publication spring.

[7] G. M. Mafuyai, I.S. Eneji, R. Sha'Ato, and L.A. Nnamonu, (2019). Heavy Metals in Soil and Vegetables Irrigated with Ex- Tin Mining Ponds Water in Barkin - Ladi Local Government Area Plateau State, Nigeria. Agriculture and Food Sciences Research, 6(2), pp. 211220.

[8] J.A. Enaam, (2013). Evaluation of Surface Water Quality Indices for Heavy Metals of Diyala River Iraq. J. Nat. Sci. Res. 3(8), pp. 63-64.

[9] F. Fenglian and W. Qi, (2011). Removal of Heavy Metal ions from Waste Waters: A review Journal of. Environmental Management. 92(3), pp. 407-418.

[10] K. Cambra, T. Martinezm, A. Urzelai, E. Alonso, (1999). Risk analysis of a farm area near a lead and cadmium contaminated industrial site. Soil sediment contamination 8, 527-540.

[11] G. J. Wagner, (1993). Accumulation of cadmium in crop plants and consequences to human health Journal of Advanced Agronomy. 51, pp. 173-212.

[12] WHO, Evaluation of Certain Food Additives and Contaminants. In: Forty-First Report of the joint FAO/WHO Expert Committee on Food Additives. WHO, Geneva, Switzerland, WHO Technical Series, 837, 1993

[13] L. Jarup. Hazards of heavy metal contamination Brit. Med. Bull 2003,68, pp. 167-182.

[14] USEPA (2012). Waste and cleanup risk assessment http://www2.epa.gov/risk/waste-and-cleanup-risk-assessment.

[15] M. A. Lushenko, (2010). A risk assessment for ingestion of toxic chemicals in fish from Imperial beach, California: San Diego State University.

[16] R. Milacic, and B. Kralj, (2003). Determination of $\mathrm{Zn}, \mathrm{Cu}, \mathrm{Cd}, \mathrm{Pb}$, $\mathrm{Ni}$ and $\mathrm{Cr}$ in some Slovenian foodstuffs. European Food Research and Technology 217, pp. 211-214.

[17] C.Y. Chang, H.Y.Yu, J.J. Chen, F.B. Li, H.H. Zhang and C.P. Liu, (2014). Accumulation of heavy metals in leaf vegetables from agricultural soils and associated potential health risks in the Pearl River Delta, South China. Environmental Monitoring and Assessment, 186, pp. 1547-1560.

[18] A. Mahmood, and R.N. Malik, (2014). Human health risk assessment of heavy metals via consumption of contaminated 
vegetables collected from different irrigation sources in Lahore Pakistan. Arabian Journal of Chemistry, 7, pp. 91-99.

[19] R.K. Badawy, A.M.A. El-Gawad and H.E. Osman,(2013). Health risks assessment of heavy metals and microbial contamination in water, soil and agricultural foodstuff from wastewater irrigation a Sahl El-Hessania area, Egypt. Journal of Applied Sciences Research, 9(4), pp. 3091-3107.

[20] K. Lock and H. de Zeeuw, (2001). Health and Environmental Risks Associated with Urban Agriculture. Urban Agricultural Management, 1, pp. 6-8.

[21] M.U. Henry, R.A. Ogenyi, U.I. Henry and O. Dogun, (2018). Assessment of Heavy Metal Concentration in Water, Soil and Vegetable in Ex-Mining Pond, Jos South L.G.A Plateau State, Nigeria. International Journal of Scientific and Research Publications, 8(8), pp. $840-845$

[22] V.N. Daniel, E.S. Chundusu and J.A. Chup, (2014). Heavy Metals Accumulation in Agricultural Soils Irrigated with Tin - Mine Water in $\mathrm{B} /$ Ladi, Plateau State, Nigeria. International Journal of Engineering \& Technology, 14(4), pp. 69-74.

[23] G.M. Mafuyai, I.S. Eneji, R. Sha'Ato and L.A. Nnamonu L.A, Heavy Metal Concentration in Soil Irrigated with Ex- Tin Mining Ponds Water, Bokkos L.G.A Plateau State, Nigeria. African Journal of Environment and Natural Science Research Volume 2, Issue 3, (2019) pp. 13-28.

[24] S. Jiya and H.D. Musa, (2012). Impact of derived Tin Mining Activities on Landuse/Land covering Bukuru, Plateau State, Nigeria Journal of sustainable Development 5(5), pp. 913-963.

[25] N.S. Chary, C.T. Kamala, and D.S.S. Raj, (2008). Assessing Risk of Heavy Metals from consuming food grown on Sewage Irrigated Soil sand food chain transfer. Ecotoxicological Journal of Environmental Safety. 69, pp. 513-524

[26] M. Lei, B. Liao, Q. Zeng, P. Qin, and S. Khan, (2008). Fraction distribution of lead, cadmium zinc and copperin metal contaminated soil before and after extraction with disodium ethylenediaminetetra acetic acid. Community soil science plant anal. 39, pp. 1963-1978.

[27] Z.Y. Hseu, Z.S. Chen, C.C. Tsai, C.C. Tsui, S.F. Cheng, C.L. Liu and H.T. Lin, (2002). Digestion Methods for Total Heavy Metals in Sediments and Soils. Water, Air and Soil Pollution, 141, pp. 189205.

[28] A.A. Adesuyi, K.L. Njoku and M.O. Akinola, (2015) Assessment of Heavy Metals Pollution in Soils and Vegetation around selected Industries in Lagos State, Nigeria. Journal of Geoscience and Environment Protection, 3, pp. 11-19.

[29] Y.J. Cui, Y.G. Zhu, R.H. Zhai, D.Y. Chen, Y.Z. Huang, Y. Qui, and J.Z. Liang, (2004). Transfer of metals from near a smelter in Nanning, China. Environmental International, 30, pp. 785-791.

[30] K. Sajjad, R. Farooq, S. Shahbaz, M.A. Khan and M. Sadique, (2009). Health risk assessment of heavy metals for population via consumption of vegetables. World Applied Sciences Journal, 6(12) pp. 1602-1606.

[31] S.C. Barman, R.K. Sahu, S.K. Bhargava and C. Chatterjee, (2000). Distribution of heavy metals in wheat, mustard and weed grown in fields irrigated with industrial effluents. Bulletin of Environmental Contamination and Toxicology, 64, pp. 489- 496

[32] S.Q. Khan, Y.M. Zheng, Y.Z. Huang and Y.G. Zhu, (2008) Health risks of heavy metals in contaminated soils and food crops irrigated with wastewater in Beijing, China. Journal of Environmental Pollution, 152(3), pp. 686-692.

[33] R.K Rattan, S.P. Datta, P.K. Chhonkar, K. Suribabu and A.K. Singh Long term impact of irrigation with sewage effluents on heavy metal content in the soils crops and groundwater - a case study. Agriculture ecosystem and environment, 109, pp. 310-322. 2005.

[34] WHO/FAO (2013) Guidelines for the Safe Use of Wastewater and food stuff; 2, pp.1 - 14: 988 Wastewater Use in Agriculture, World Health Organization, Geneva.

[35] I. Lente, J. Ofosu-Anim, A.K. Brimah and S. Atiemo, (2014). Heavy metal pollution of vegetable crops irrigated with wastewater in Accra, Ghana. West African Journal of Applied Ecology, 22(1), pp. $41-58$

[36] K.U. Osuocha, E.C. Chukwu, E.A. Ugbogu, O.C. Atasie and C.E Ogbonna, (2016). Effects of Quarry Mining activities on The Nutritional Composition of Edible Vegetables in Ishiagu, Ebonyi State, Nigeria. Journal of Experimental Biology and Agricultural Sciences, 4(5), pp. 467-474

[37] WHO/FAO, (2007). Joint FAO/WHO Food Standard Programme Codex Alimentarius Commission 13th Session. Report of the Thirty Eight Session of the Codex Committee on Food.

[38] A.K. Chopra and C. Pathak, (2012). Bioaccumulation and translocation efficiency of heavymetals in vegetables grown on long term wastewater irrigated soil near Bindal river, Dehradun. Agricultural Research, 1(2), pp. 157-164.

[39] S. Singh, M. Zacharias, S. Kalpana and S. Mishra, (2012). Heavy metals accumulation and distribution pattern in different vegetable crops. Journal of Environmental Chemistry and Ecotoxicology, 4 pp $75-81$

[40] B.W. Tukura, A.C. Etonihu, I.A. Ambo and T. Iboro (2016). Accumulation of heavy metals in vegetables grown on farmlands irrigated with treated sewage water. FUTN Trends in Science and Technology Journal. 1(1) pp. 168-172.

[41] G.A. Boamponsem, M. Kumi and I. Debrah, (2012). Heavy metals accumulation in cabbage, lettuce and carrot irrigated with wastewater from Nagodi mining site in Ghana. International Journal of Scientific and Technology Research, 1(11), pp. 124-129.

[42] S. Roy and G. Gupta (2013). Effect of wastewater irrigation on soil and some selected vegetables grown in Asansol, West Bengal. International Journal of Environmental Sciences 6 (5), pp. 894 904.

[43] USEPA, (2010). Risk-based oncentration Table. United State Environmental Protection Agency, Washington, DC, 2010.

[44] L.T. Bambara, K. Kabore, M. Derra, M. Zoungrana, F. Zougmore and O. Cisse, (2015). Assessment of heavy metals in irrigation water and vegetables in selected farms at Loumbila and Paspanga, Burkina Faso. IOSR Journal of Environmental Science, 9(4), pp. 2319-2399.

[45] M.S. Brar, S.S. Mahli, A.P. Singh, C.L. Arora and K.S. Gill, 2000. Sewer water irrigation effects on some potentially toxic trace elements in soil and potato plants in northwestern India. Canadian Journal of Soil Science, 80 pp. 465-471.

[46] T. Akabzaa, B. Banoeng-Yakubo and J. Seyire, (2009). Impact of mining activities on water resources in the vicinity of the Obuasi mine. West African Journal of Applied Ecology, 11(1). http://doi.org/10.4314/wajae.v11i1.45719.

[47] R. Bharose, S.B. Lal, S.K. Singh and P.K. Srivastava, (2013). Heavy metals pollution in soil-water-vegetation continuum irrigated with ground water and untreated sewage. Bulletin of Environmental and Scientific Research, 2(1), pp. 1-8.

[48] WHO, (2010). World Health Organization Water for Health Guidelines for Drinking-Water Quality. Geneva: World Health Organization

[49] WHO (2001). World Health Organization Codex Alimentarius Commission, Food additives and contaminants. WHO food standards Programme, ALINORM 10/12A:1-289. Fertilizer and their efficient use.

[50] V.N. Daniel, E.S. Chudusu, J.A. Chup and N.D Pius, (2014). Variation of Heavy Metals in Agricultural Soils Irrigated with Tin Water in Heipang District of Barkin Ladi, Plateau State, Nigeria. International Journal of Science and Technology, 3(5), pp. 674-683.

[51] A.K. Ratul, M. Hassan, M.K. Uddin, M.S. Sultana, M.A. Akbor and M.A. Ahsan, (2018). Potential health risk of heavy metals accumulation in vegetables irrigated with polluted river water.International Food Research Journal, 25(1), pp. 329-338.

[52] S.K. Awashthi, (2000). Prevention of Food Adulteration Act no. 37 of 1954. Central and State Rules as Amended for 1999, Ashoka Law House, New Delhi.

[53] A.K. Ghosh, M.A. Bhatt and H.P. Agrawal, (2012). Effect of longterm application of treated sewage water on heavy metal accumulation in vegetables grown in northern India. Environmental Monitoring and Assessment, 184, pp. 1025-1036.

[54] V. N. Daniel, E. S. Chundusu, and J. A. Chup (2014). Heavy Metals Accumulation in Agricultural Soils Irrigated with Tin - Mine Water in $\mathrm{B} / \mathrm{Ladi}$, Plateau State, Nigeria. International Journal of Engineering \& Technology, 14(4), pp.69-74.

[55] EU, (2002). European Union. Heavy Metals in Wastes, European Commission on Environment (http://ec.europa.eu/environment/waste/studies/pdf/heavymetal sreport.pdf).

[56] W.J. Sanok, G.E. Joseph, L.M. Kerry, H.G. Walter and J.L. Donald. Residues of arsenic and lead in potato soils on Long Island. Chemosphere, 30(4), pp. 803-806.1995

[57] T. Takamatsu, H. Aoki and T. Yoshida. Determination of arsenate, arsenite, monomethylarsonate, and dimethylasinate in soil polluted with arsenic. Soil Science. 1982.133, pp. 239-246.

[58] O.J. Dorcas, N.E. Joseph and J.S. Sunday, (2016). Determination of the Contamination Levels of Cadmium, Lead, Arsenic and Mercury in the Vegetables from Old Mining Site of Jos Plateau, Nigeria. 
International Journal of Interdisciplinary Research and Innovations, 4(2): $40-44$

[59] H.M. Naser, S. Sultana, N.U. Mahmud, R. Gomes and S. Noor, (2011). Heavy metal levels in vegetables with growth stage and plant species variation. Bangladesh Journal of Agricultural Research, 36(4), pp. 563-574.

[60] M. Al-Jaboobi, A. Zouahri, M. Tijane, A.E. Housani, Z. Mennane, H. Yachou and M. Bouksami, (2014). Evaluation of heavy metals pollution in groundwater, soil and some vegetables irrigated with wastewater in the Skhirat region "Morocco". Journal of Materials Environmental Science, 5(3), pp. $961-966$

[61] T.F. Duressa and S. Leta, (2015). Determination of Levels of As, Cd, $\mathrm{Cr}, \mathrm{Hg}$ and $\mathrm{Pb}$ in Soils and Some Vegetables Taken from River Mojo Water Irrigated Farmland at Koka Village, Oromia State, East Ethiopia. International Journal of Science: Basic and Applied Research. (21), pp. 2.

[62] E.O. Orish, A.D. Emmanuel, O.C.M. Herbert and A.U. Nnaemeka (2017). Lead Levels in Vegetables from Artisanal Mining Sites of Dilimi River, Bukuru and Barkin Ladi North Central Nigeria: Cancer and Non-Cancer Risk Assessment. Asian Pac Journal Cancer, 18(3), pp. $621-627$

[63] A. Yadav, P.K. Yadav and D.N. Shukla, (2013). Investigation of heavy metal status in soil and vegetables grown in urban area of Allahabad, Uttar Pradesh, India. International Journal of Scientific and Research Publications, 3(9), pp. 1-7.

[64] z. Saglam, (2013). Heavy Metal Accumulation in Edible Parts of Some Cultivated Plants and Media Samples from a Volcanic Region in Southern Turkey. Ecology, 22(86), pp.1-8.

[65] R.K. Sharma and M. Agrawal, (2006). Effects of single and combined treatments of $\mathrm{Cd}$ and $\mathrm{Zn}$ on carrot plants: uptake and bioaccumulation. Journal of Plant Nutrition 29, pp. 1791-1804.

[66] R. Auta, S. A. James T. Auta and E. M. Sofa (2011). Nutritive value and Phytochemical Composition of Processed Solanum incanum (Bitter Garden Egg). Science World Journal, (3):5-6.

[67] L. Shibao, W.L. Jianhua and P. Liang, (2016). Study on the Effects of irrigation with reclaimed water on the content and distribution of heavy metals in soil. International Journal of Environmental Research and Public Health, 13, pp. 298-308.

[68] FAO/WHO (2011). Joint FAO/WHO Food Standard ProgrammeCodex Committee on Contaminants in Foods; Fifth Session, pp. 64-89.

[69] Y.N. Jolly, S. Akter, J. Kabir, and A. Islam, A. (2013). Health risk assessment of heavy metals via dietary intake of vegetables collected from an area selected for introducing a nuclear power plant Research Journal of Physical and Applied Sciences, 2(4) pp. 43-51.

[70] G. Benti, (2014). Assessment of heavy metals in vegetables irrigated with Awash River selected farms around Adama town, Ethiopia. Afrcan Journal of Environmental Science and Technology, 8(7) pp. $428-434$

[71] Q. A. Abdul, K. Qudsia, B. Ruqia and Y. Balal, Accessing Potential Bioaccumulation of Heavy Metals in Selective Vegetables from Gujranwala District, Pakistan. Journal of Environment and Earth Science, 2015, 5(8) pp.58-70.

[72] A. Kumar and V. K. Seema, (2017). Human Health Risk of Heavy Metals in Vegetables Grown in Contaminated Soil Irrigated with Sewage Water. American Journal of Food Science and Nutrition, 4(4), pp. 23-35

[73] EPA, Environmental Protection Agency Parameters of Wate Quality. Interpretation and Standards, Johnstown Castle Co. Wexford Irelan, 2001, pp.82.

[74] T.J. Srinivasan and R.V. Reddy. Watse Water Irrigation in India: An Analyaisof Its Heath Impact. A Conference Paper of INSEE, Centre for Economic and Social Studies, Nizamiah Observatory Campus, Begumpet, Hyderabad, 2009.

[75] M. Muchuweti, J.W. Birkett, E. Chinyanga, R. Zvauya, M.D. Scrimshaw and J.N. Lester, (2006). Heavy metal content of vegetables irrigated with mixture of wastewater and sewage sludge in Zimbabwe: implications for human health. Agriculture, Ecosystem and Environment, 112, pp. $41-48$.

[76] A. Kumar, I.K. Sharma, A Sharma, S. Varshney, P.S. Verma, (2009). Heavy metals contamination of vegetable foodstuffs in Jaipur (India). Electronic Journal of Environmental, Agricultural Food Chemistry 8(2), pp. $96-101$.

[77] A.K. Ibrahim, H. Yakubu and M.S. Askira, (2014). Assessment of heavy metals accumulated in wastewater irrigated soils and lettuce (Lactuca sativa) in Kwadon, Gombe State, Nigeria. AmericanEurasian Journal of Agricultural and Environmental Sciences, 14 (6) pp. 502-508
[78] J. Smit and B. Nasr, (1992). Urban agriculture for sustainable cities: Using wastes and idle and and water bodies as resources. Environment and Urbanization, 4(2): pp.141-152.

[79] G. M. Mafuyai, U. Shaapera and S.M. Ayuba (2020). Enrichment and Geoaccumulation of $\mathrm{Pb}, \mathrm{Zn}$, As, Cd, Mn and $\mathrm{Cr}$ in Farm Soils around Tin Mine Areas in Plateau State, Nigeria. African Journal of Environment and Natural Science Research, 3(2):pp.22-31.

[80] B. Mohsen, and S. Mohsen, American-Eurasian. J. Agric. Environ. Sci. 4: 86. 2006.

[81] B. H. AZita and A. M. Seid, Warld Academy of Sciece, Engineering and Technology 43: 56. 7. 2008

[82] M.J. McLaughlin, D.R. Parker and J.M. Clarke, Field Crops Research 60:143. 8, 1999.

[83] M. A. Lushenko, A risk assessment for ingestion of toxic chemicals in fish from Imperial beach, California: San Diego State University.2010.

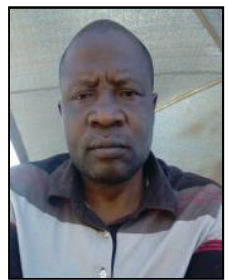

Dr. Mafuyai Godwin Magit was born on the 24th march 1968 at Kunet (Butura) in Bokkos Loca Government Area of Plateau State, Nigeria. He attended L.E.G.D Butura Gida were he obtained his First Leaving Certificate in 1979 and went to G.S.S Butura Kampani for his secondary education and completed in 1988 .

He enrolled in the Nigerian Institute of Science Laboratory Technology Ibadan study center at the prestigious University of Jos, and obtained the following qualifications; Basic Technology Certificate in 1992, National Diploma, 1994 in Science Laboratory Technology and Higher National Diploma in Chemistry/Biochemistry Techniques 1996. He became a chartered Fellow of Nigerian Institute Science Laboratory Technology Ibadan in 2009. He then proceeded to Federal University of Agriculture Makurdi, Benue State where he obtained his Master of Science and Doctorate Degree (PhD) in Environmental Chemistry in 2014, and 2020, respectively.

He has attended several scientific conferences/workshops in Nigeria has many Publications in reputable International Journals on Heavy Metals Pollution on the Environmental and is Membership of the following Professional Bodies: Fellow (Chartered) Nigerian Institute of Science Laboratory Technology (NISLT), Professional Member, Institute of Chartered Chemists of Nigeria (ICCON). Member, Chemical Society of Nigeria (CSN)

Dr. G. M. Mafuyai is currently a Senior Chief Laboratory Technologist in charge of Analytical Equipment in Chemistry Department University of Jos.

He is happily married to Victoria Godwin and the union is blessed with four children two boys, two girls. 